\title{
THE IMPACT OF FINANCIAL EDUCATION AND SOCIOECONOMIC STATUS ON THE UNDERGRADUATE STUDENTS' FINANCIAL LITERACY
}

\author{
Khusaini Khusaini \\ Universitas Islam Syekh-Yusuf, Indonesia \\ Email: khusaini@unis.ac.id (corresponding author) \\ Bambang Mardisentosa \\ Universitas Islam Syekh-Yusuf, Indonesia \\ Email: bmardi@unis.ac.id \\ Asep Ferry Bastian \\ Universitas Islam Syekh-Yusuf, Indonesia \\ Email:a.ferry.bastian@unis.ac.id \\ Ruhiyat Taufik \\ Universitas Islam Syekh-Yusuf, Indonesia \\ Email:rtaufik@unis.ac.id \\ Windi Widiawati \\ Universitas Islam Syekh-Yusuf, Indonesia \\ Email: widiawindiw@gmail.com
}

Received: August 2021; Accepted: November 2021; Available online: January 2022

\begin{abstract}
Financial literacy is a crucial variable for researchers and policymakers because financial literacy's contribution encourages inhabitants to organize future financial planning and decision improvement. The study aims to empirically investigate the determinants of financial literacy such as financial education, parents' socioeconomic status, and gender. The authors used a cross-sectional survey approach with $\mathrm{N}=325$ samples. The result of measuring students' financial literacy showed a moderate condition (moderate level). The multiple linear regression models showed that parents' socioeconomic status significantly improved students' financial literacy. Meanwhile, financial education and gender did not prove significant in influencing students' financial literacy. The empirical study generated that encouraging parents is one of the essential policy elements in improving students' financial literacy. The higher students' socioeconomic status tends to encourage better financial planning and decision because they comprehend the literacy skills.
\end{abstract}

Keywords: financial education; financial literacy; gender; socioeconomic status.

\begin{abstract}
Abstrak
Literasi keuangan menjadi salah satu variabel penting bagi peneliti dan pembuat kebijakan karena kontribusi literasi keuangan mendorong penduduk untuk menyusun perencanaan keuangan dan perbaikan keputusan di masa depan. Penelitian ini bertujuan untuk mengetahui secara empiris faktor-faktor penentu literasi keuangan seperti pendidikan keuangan, status sosial ekonomi orang tua, dan jenis kelamin. Penulis menggunakan pendekatan survei cross sectional dengan $N=325$ sampel. Hasil pengukuran kemampuan literasi keuangan mahasiswa menunjukkan kondisi cukup (medium). Model regresi linier berganda menunjukkan bahwa status sosial ekonomi orang tua berkontribusi signifikan dalam meningkatkan literasi keuangan mahasiswa. Sedangkan pendidikan keuangan dan gender
\end{abstract}


tidak terbukti signifikan mempengaruhi literasi keuangan mahasiswa. Hasil studi empiris berkontribusi dalam menjadikan orang tua sebagai salah satu elemen penting kebijakan peningkatan literasi keuangan mahasiswa. Mahasiswa dengan status sosial ekonomi yang lebih tinggi cenderung mampu menyusun rencana dan keputusan keuangan lebih baik, karena memiliki kemampuan literasinya.

Kata kunci: gender; literasi keuangan; pendidikan keuangan; status sosial ekonomi.

How to Cite: Khusaini, K., Mardisentosa, B., Bastian, A. F., Taufik, R., \& Widiawati, W. (2022). The Impact of Financial Education and Socioeconomic Status on the Undergraduate Students' Financial Literacy. Media Ekonomi dan Manajemen, 37(1), 55-76. doi: http://dx.doi.org/10.24856/mem.v37i1.2385.

\section{INTRODUCTION}

Recently, financial literacy has been the core attention of researchers and policymakers in various countries, including Indonesia. It is triggered by the eagerness in every country to improve society's welfare and encourage society to have good foresight to manage the finance (Organisation for Economic Co-operation and Development, 2020). Financial literacy is a life skill that contributes to individuals' welfare, families, investment decision, and the broader economy (Oseifuah et al., 2018; Senda et al., 2020). With the ability to understand financial concepts and skills, humans can manage financial resources and the important financial reform efforts to reduce poverty (Askar et al., 2020) and had financial resilience, so they could survive the crisis (Setyorini et al., 2021). Also, lack of financial literacy drives people's inability to choose the best option for them (Soseco et al., 2018).

The previous research on the students' financial literacy in high school likes (Grohmann \& Menkhoff, 2015; Jayaraman \& Jambunathan, 2018; Khusaini et al., 2021) in higher education (Ansong \& Gyensare, 2012a; Chen \& Volpe, 2002; Hanson \& Olson, 2018; Kadoya \& Khan, 2020; Melmusi, 2017; Oseifuah et al., 2018; Radityas \& Pustikaningsih, 2019; Rafinda \& Gal, 2020; Seotsanyana, 2019; Setiawan, 2020; Silta \& Miharti, 2020; Suherman et al., 2020) as the object of the research. According to these various studies, authors' most common investigation was the students in higher education. However, authors had differences in identifying the determinants of student's financial literacy in higher education. These differences encourage the authors to examine the variables of financial education, socioeconomic status, gender, and control variables simultaneously on financial literacy, complement the existing literature, and increase the consistency of research results.

The various researcher investigated to determine the level of financial literacy. The result illustrated that generally, the level of financial literacy is in a low category. A higher level of national income is insufficient for society to encourage higher financial literacy (Lusardi, 2019). Other studies in the various country illustrated similar results, for instance, in California, Kentucky, Ohio, Florida, Massachusetts, Pennsylvania (Chen \& Volpe, 2002), and Ghana (SarpongDanquah et al., 2018).

Financial literacy was a low category in Indonesia; therefore, the government pays attention to financial literacy through the state institution that regulates finances and oversees financial service activities, namely the Financial Services Authority (OJK). In 2019, the OJK conducted financial literacy surveys. The result showed the financial literacy index in Indonesian by $38.03 \%$ (Otoritas Jasa Keuangan, 2019). It illustrated that there had been an improvement in society's knowledge and comprehension of financial literacy by $9.37 \%$. However, Indonesia's development of financial literacy was still left behind rather than in Southeast Asia 
countries such as Malaysia, Singapore, Thailand, and Vietnam.

Financial literacy is elaborated the finance introduction and as a concept of managing and controlling the finances in income and expenses that must have a balanced percentage so that financial conditions continue to improve wisely. (Chen \& P. Volpe, 1998) found that students with low-level knowledge possibly make wrong decisions in their finance. Students who have low ability in financial literacy will make a mistake in deciding their consumption. It is caused students' consumption will not have the ability to prioritize their needs.

This study was within the scope of recent literature that focuses on assessing the effectiveness of financial education programs (Lusardi \& Mitchell, 2014; Xu \& Zia, 2012). Financial education is the process of providing information and instruction to society, consumers, and employees to improve their knowledge and comprehension of financial concepts and products (Mishra, 2019). Improving youth financial literacy in developing countries is through education such as the length of education activity and the quality of education (Özdemir, 2019). A similar result found that education influenced financial knowledge (Brugiavini et al., 2020).

Moreover, if the students' can finish their education, they will find selfmeasured financial literacy and satisfaction in managing their finance (Gerrans \& Heaney, 2019). Atkinson \& Messy (2012) found the low level of financial in school, which is indicated by the incomplete facilities in school and education process outside of middle school activities implied the higher financial literacy level. Wagner \& Walstad (2019) inferred that the current education contributes to a more positive and more robust effect on students' attitude on long-term behavior. It is also supported by (Cordero et al., 2019), which concluded that the financial education program would affect students if taught as part of other subjects, such as through a cross-curricular approach. However, (Becchetti et al., 2013) did not significantly affect the treatment of financial literacy but contributed a positive impact on the behavior hypothesis. Lührmann et al. (2015) found the positive effect on shortterm training sessions in financial attitudes such as the interest of financial matters and saving reserves.

Cole et al. (2009) described a positive correlation between cognitive and financial literacy in India and Indonesia. Some studies illustrated that there was a significant relationship between financial literacy and educational achievement. Higher education level implied high financial literacy (Garcia \& Tessada, 2013; Lusardi, 2003), and lower education level tends to affect a lack of comprehension about financial literacy (Lusardi \& Mitchell, 2011b). Students comprehend the mathematical and physical subject very well; consequently, they have a higher understanding of financial literacy (Herd et al., 2012). Meanwhile, other studies illustrated no relationship between education and financial literacy (Chen \& Volpe, 2002; Jariwala, 2015).

Socioeconomic status in family net income, types of jobs, educational achievement, marital status, and the number of family members was used by (Gerardi et al., 2010; Van Campenhout, $2015)$ to predict financial literacy. Socioeconomic influenced youth financial literacy, and there was a correlation between financial knowledge, attitudes, and behavior (Garg \& Singh, 2018). The higher parents' income contributed to the possibility of their children's financial literacy than the lower level of parents' income (Oseifuah et al., 2018; Thompson, 2014). Also, family background promoted a positive correlation toward financial knowledge (Mimura et al., 2015). In contrast with some research findings, students' socioeconomic condition negatively influenced students' financial literacy scores in the United States 
(Bumcrot et al., 2013; Lusardi \& Mitchell, 2013). Students in low-income family conditions tend to have a higher level of financial literacy.

Furthermore, gender is one of the determinants variables of financial literacy. Female students had a higher level of financial literacy rather than male students (Margaretha \& Pambudhi, 2015; Wijayanti et al., 2016). However, other findings illustrated the contrast result. The result showed that male students have a higher level of financial literacy rather than female' students (Almenberg \& SäveSöderbergh, 2011; Lantara \& Ni Ketut Rai Kartini, 2015; Lusardi \& Mitchell, 2014; Mustapha. \& Jeyaram, 2015). There were some differences in financial literacy among female and male students. Some factors that caused the lower level of financial literacy in female students are the emotional control of female students. In addition, commonly, male students have logic and simple thinking. They also more courageous and confident in making decisions. Then, other studies illustrated that gender variable did not influence students' financial literacy (Egesta et al., 2021; Irman, 2018; Rita \& Pesudo, 2014; Suherman et al., 2020).

Based on the brief description above, previous researchers produced inconsistent findings of the relationship between financial education, parents' socioeconomic status, and gender with financial literacy. In addition, the measurement of financial literacy is limited to general knowledge of finance, savings and loans, insurance, investment, and risk management (Cole et al., 2009; Klaper et al., 2015; Lusardi, 2003; Lusardi \& Mitchell, 2014). In this study, the researchers re-examined the effect of financial education variables, socioeconomic status, gender and control variables on financial literacy in order to increase the consistency of research results. The researcher also completes the measurement of the previous financial literacy variable by adding an indicator of basic macroeconomic knowledge (Wagner \& Walstad, 2019). With the addition of new indicators on financial literacy, aspects of financial literacy become more complete. These results are expected to make a real contribution in expanding the study of financial literacy by taking into account the macroeconomic aspects. Financial decisions are also not only based on financial aspects, but also economic aspects.

Second, this research is one of the few studies that combine the financial education role, socioeconomic status, gender variable in making a financial decision for students. Then, the third, this research provided empirical evidence for the relevance of various types of financial literacy. We expected the current study to produce the significant influence of financial education, socioeconomic status, gender, and control variables on students' financial literacy.

\section{LITERATURE REVIEW}

Compen et al. (2019) stated that financial literacy is a broad knowledge about finance that covers the discussion about attitude and behavior in managing finances in the long term. According to (Susanti \& Hardini, 2018), financial literacy was the knowledge, beliefs, and skills to improve someone's sensitivity toward financial products and services. Furthermore, Sarpong-Danquah et al. (2018) stated that financial literacy goals were to measure to what extent the individual can comprehend the financial literacy problem and decide how to manage their finances. Financial literacy is the level of human capital associated with the financial lives of consumers. Financial literacy describes as the level of aggregate from the three components such as knowledge and comprehension, attitude and self-confidence dimensions, and skills and opportunities (Son \& Park, 2019). From the explanation above, we conclude that financial literacy is knowledge to help 
individuals understand managing finance well to get a prosperous life in the future.

Chen \& P. Volpe (1998) stated that the dimensions of financial literacy were personal finance, loans and savings, insurance, and investment (such as mutual fund investment). Meanwhile, Nababan \& Sadalia (2012) stated five comprehension aspects in financial literacy: the basic knowledge of finance, financial management, credit management, savings, investment, and risk management.

Every human has different abilities and comprehension of finance. It is caused by many factors that influence financial literacy. Those determinant factors are age, work experience, educational background, and college majors (Ansong \& Gyensare, 2012b). Based on Oseifuah et al. (2018), financial literacy was examined by gender, age, study program, study year, parents' income, parents' education, and students' financial status. Homan (2015) stated that gender, residence, parents' education, and the year of entrance influence financial literacy. Furthermore, Shaari et al. (2013) described that age, gender, spending habit, and the length of study are the affected factors of financial literacy. The determinants factors of financial literacy are individual characteristics such as age, gender, repetition number, grade, mathematical skill, reading skill, population status, completed education, and classroom learning (Salas-Velasco et al., 2020).

Brugiavini et al. (2020) inferred that the students' activities determine students' financial literacy before and after participating in online learning by using the application. The financial- materials taught by higher education institutions are proven to improve students' financial knowledge, build the main financial literacy skills, and increase financial activities better during and after education (U.S. Financial Literacy and Education Commission, 2019). Another empirical study investigated by (Cordero et al., 2019) proved that the availability of financial education positively and significantly related to students' financial literacy except to the applied strategy for teaching the financial concept. This study confirmed the previous study (Cole et al., 2009; Garcia \& Tessada, 2013; Herd et al., 2012; Lusardi, 2003; Lusardi \& Mitchell, 2011a; SalasVelasco et al., 2020). However, the contrary studies stated that the unrelated between the availability of financial education and financial literacy. This study concluded no correlation between financial education and financial literacy (Chen \& Volpe, 2002; Jariwala, 2015).

Other studies found that gender, department, parents' income, parents' education, and year of entrance to predict students' financial literacy (Silta \& Miharti, 2020) students' achievement of the economic and non-economic score (Rafinda \& Gal, 2020), income-generating activities, formal education, political protection, discrimination level, poverty and migration, credit, the improvement of marginal income, infrastructure, unemployment, and ethnicity (Nanda \& Samanta, 2018).

Financial education can be a compulsory or elective course introduced in the school curriculum as a separate subject (independent subject) or crosscurricular (Organisation for Co-operation and Development, 2013). The provision of financial education in schools, colleges, workplaces, and the larger community has proven to be a solution to improve financial literacy appropriately (Lusardi, 2019).

The school has to develop an interest in financial education broadly. Students in primary and secondary school should have a good financial education to make a financial decision based on the daily information and encourage students to make savings for their future (SalasVelasco et al., 2020). Financial education is a process of providing information and instruction to citizens, consumers, and employees to improve their knowledge and comprehension of financial concepts and 
financial products (Mishra, 2019). Financial education starts to become a variable and tool of important policy in improving the well-being of individual finances. To improve the youth financial literacy in developing countries through education that is an appropriate way, such as the length of the education process and the quality of education (Özdemir, 2019). Melmusi (2017) stated that effective and efficient learning activities support students in encouraging the ability to comprehend, assess, and act for their financial interests.

Similar findings are founded by (Brugiavini et al., 2020; Carpena \& Zia, 2020). Those findings inferred that education influences financial knowledge. In addition, if the students can finish their education, they will assess their financial literacy by themselves and satisfy to manage their finances (Gerrans \& Heaney, 2019). Also, education can affect the individual financial literacy on to what extent the individual is more educated in accessing and processing the information easily. (Atkinson \& Messy, 2012) found that the incomplete school' facilities indicate the lower level of students' financial literacy, and the education except in middle school indicates the higher level of students' financial literacy. In fact, (Wagner \& Walstad, 2019) inferred financial education contributed a more positive and more robust effect on the long-term students' behavior.

It was also supported assertively by research findings by Cordero et al. (2019) inferred that financial education programs could impact students if they learn as part of other subjects, such as a cross-curricular approach. Cole et al. (2009) found a significant positive correlation between cognitive and financial literacy in India and Indonesia. Some previous research illustrated a significant correlation between financial literacy and education outcomes (Garcia \& Tessada, 2013; Lusardi, 2003). Then, lower education tends to lack comprehension of finance (Lusardi \&
Mitchell, 2011b). Students with algebra, trigonometry, and physics have a high understanding of financial literacy and the school's characteristics and asset values (Herd et al., 2012).

Other research findings also illustrated that the availability of financial training contributes positively and significantly to students' financial literacy except for the applied strategy for teaching the financial concept, even though the effect occurs relatively small when considering the potential presence of significantly different between countries. Another finding that students who get the additional course that professionals teach from private institutions and nongovernmental institutions obtained better results than students who learned financial education training from their teachers in school (Cordero et al., 2019). Similar research illustrated the positive correlation between certain ways of providing financial education and developing students' financial skills (Salas-Velasco et al., 2020).

A small number of previous research stated that education did not correlate with financial literacy. Those studies concluded no correlation between education and financial literacy (Son \& Park, 2019). Another research also obtained similar results that there was no influence of financial education on financial literacy among high school students (Mandell, 2008). We stated the hypothesis:

$\mathbf{H}_{1}$ : Financial Education Significantly Affects Financial Literacy.

\section{Socioeconomic status} describes someone, family, or society's economic condition related to income, education, wealth, jobs, and position aspects. Every individual or family desires a good socioeconomic status condition, but most are still in the lower condition (Indrawati et al., 2015). The socioeconomic condition can be defined as the condition that illustrates family financial ability and the sufficient of their 
finances (Basrowi \& Siti, 2010). Meanwhile, Zhao et al. (2012) implied that the condition of students' individual is constructed by the parents' level of education, parents' occupations, and the family resources or wealth. At a different time, Liu et al. (2020) defined SES as the parents' condition with the higher-level education, the decent income and jobs, the family resources, and the SES index.

A similar measurement of students' family's economic status was employed by (Yuxiao \& Chao, 2017). Based on Yuxiao \& Chao (2017), there are four categories of students' family's economic status: parents' occupation, parents' income, parents' education, and parental membership in certain political organizations or parties. Mishra (2019) employed parents' income and asset ownership as the socioeconomic aspect. However, some researchers described parents' socioeconomic status specifically by measuring family' income, family education, assets ownership, and occupations as separate variables (Jayaraman \& Jambunathan, 2018; Radityas \& Pustikaningsih, 2019; Riitsalu et al., 2018; Silta \& Miharti, 2020; Suherman et al., 2020). According to those opinions, the parents' socioeconomic status (SES) indicators include parents' income, family' assets or facilities, parents' education, and parents' occupation.

Previous research has investigated the factors of individual socioeconomic factors that influence financial literacy and its dimensions. Financial literacy levels tend to increase with income improvement (Lusardi et al., 2009). Jariwala (2015) investigated the level of financial literacy in the group of lower-income. Socioeconomic status consists of the net of family income, jobs types, education achievement, marital status, and the number of family members (Gerardi et al., 2010; Van Campenhout, 2015). They investigated that various socioeconomic status influences youth financial literacy and a correlation between financial knowledge, financial attitude, and financial behavior (Garg \& Singh, 2018).

Regarding the influence of household economic conditions, a strong negative correlation between the average index score of financial literacy in the state and state poverty in the United States. Countries with a higher level of financial literacy tend to have a lower level of poverty and vice versa (Bumcrot et al., 2013; Lusardi \& Mitchell, 2013). These findings guided the policymakers and practitioners who are interested in the lower-level financial literacy areas.

Another study conducted in Indonesia by (Silta \& Miharti, 2020) inferred that socioeconomic status measured with parents' education and income insignificantly influences financial literacy. Meanwhile, a mother's education level significantly affects financial literacy and contrasts with the father's education and income (Radityas \& Pustikaningsih, 2019). However, findings concluded that a father's education and income influence financial literacy (Suherman et al., 2020). The hypothesis was:

$\mathbf{H}_{2}$ : The Parents' Socioeconomic Status Significantly Affects Financial Literacy.

Munisah and Khusaini (2017) defined gender as individual differences based on biological factors brought from birth. In general, man and woman acquire specific conditions which are both biologically and psychologically different. Gender measurement was commonly explored as the main research variable by previous researchers. The finding that a gap in financial literacy among citizens, both male, and female (Blasch et al., 2018). Studies showed that female students in universities have a higher level of financial literacy than male students (Becchetti et al., 2013; Margaretha \& Pambudhi, 2015; Wijayanti et al., 2016). However, other findings showed the opposite, where male students have the highest literacy levels (Almenberg \& SäveSöderbergh, 2011; Lantara \& Ni Ketut Rai 
Kartini, 2015; Lusardi \& Mitchell, 2014; Mustapha. \& Jeyaram, 2015). With a correlational research approach, gender was proven to significantly affect the increase of financial literacy (Oseifuah et al., 2018; Xue et al., 2019).

The difference in financial literacy level where women tend to have lower than men is because of several factors: women's emotional state and less capability on self-control. Meanwhile, the man generally has logical and simple thinking when deciding something and more courageous and confident in making decisions. However, other opinions, some researches showed that gender did not affect students' financial literacy (Blasch et al., 2018; Egesta et al., 2021; Irman, 2018; Irman \& Fadrul, 2018; Rita \& Pesudo, 2014; Salas-Velasco et al., 2020; Silta \& Miharti, 2020; Suherman et al., 2020). We wrote a hypothesis:

$\mathbf{H}_{3}$ : Gender Significantly Affects the Financial Literacy

\section{RESEARCH METHODS}

The authors focused on the empirical and objective analysis of the impact of financial education and socioeconomic status on the financial literacy of SyekhYusuf Islamic University's students. This research conducted a cross-sectional online survey because the data was obtained by implementing an online survey through a Google Form. The population of this research was registered and active undergraduate students of the Syekh-Yusuf Islamic University 2019/2020, as many as 4,346 students registered in the Indonesian Directorate of Higher Education Database (Forlap DIKTI). The sample was determined using the (Blasch et al., 2018) method with a sampling error of $5 \%$. Therefore, we obtained 325 samples. The sampling technique used a simple random sampling technique. We collected the data via Google Form by using a questionnaire and distributed it through WhatsApp groups. We also tested the instrument with the validity and reliability test.
Measurement mapped the dominating aspect, which becomes another aspect of the range based on the applicable rules (Kothari, 2004). The financial literacy variable $(F L)$ was measured by basic knowledge of macroeconomics, knowledge of finance, insurance, investment, savings, loans, and risk management. The Likert scale used the range 1 - 5 (Strongly Disagree - Strongly Agree). The financial education variable $(F E)$ was measured by a dummy variable, namely students who had attended financial education $=1$, others $=0$. Socioeconomic Status (SES) was measured by father's income, mother's income, father's education, mother's education, father's type of work, mother's type of work, and asset ownership. The Likert scale used is $1-5$ (Strongly Disagree Strongly Agree).

The gender is measured by a dummy variable, namely if female student $=1$, other $=0$. Prior school $(P S)$ is measured by a dummy variable, namely senior high school/equivalent $=1$, others $=0$. Faculty $(F)$ was measured by a dummy variable, namely faculties with Economics Education, Economics, Accounting, and Administration Science study programs = 1 , others $=0$. The variable dummy measured the marital status variable $(M S)$, if married $=1$, other $=0$. The work status $(W S)$ is also measured by a dummy variable, namely students who work $=1$, others $=0$. Age $(A)$ was measured by the age of students when the research takes place. Students' birth serial numbers measure the birth order number $(B O N)$.

The number of siblings (NS) was measured by the number of siblings in a family. The number of family members $(F M)$ was measured by the number of family members who live in the house. Involvement in student organizations (ISO) was measured with a dummy variable: actively involved $=1$, others $=0$. Ethnicity (ET) was measured by a dummy variable as well, if parents were Javanese $=1$, other $=0$. Parents' demographic status $(P D S)$ 
was measured by a dummy variable, namely immigrant family $=1$, others $=0$. The area of students' live $(R)$ is measured by a dummy variable, urban $=1$, rural $=0$. A dummy variable measures the distance $(D)$ between the house and campus: distance $<5 \mathrm{~km}=1$, others $=0$.

Before analyzing the data, the requirement testings and classical assumptions are carried out first. The tests include normality test, multicollinearity test, and heteroscedasticity test. The normality test of the data was conducted by applying the Chi-square test. The multicollinearity test aimed to identify the linear relationship between independent variables in the regression model. If there was a very strong or nearly perfect linear relationship in the model, it was stated that the regression model contained a multicollinearity problem. The authors used the Values of Tolerance and variance inflation factor $(V I F)$. The criteria set is if the tolerance value $>0.1$ and $V I F<10$, it was concluded that the model does not contain multicollinearity problems (Ghozali, 2016).

Meanwhile, a heteroscedasticity test investigated whether there was an inequality of variance from the residual of one observation to another observation in the regression model (Ghozali, 2016). A good regression model is one with homoscedasticity or no heteroscedasticity. The test in this study uses a correlation/relationship between independent variables and Unstandardized Residual. There was a heteroscedasticity problem that the probability value is < 0.05 . If the probability value is $>0.05$, then there is no heteroscedasticity problem. The authors then used the $t$-test and the simultaneous test with the $F$-test to test the partial hypothesis. Testing the model with the goodness of fit is used to test the feasibility of the model, whether the model is following the data used in the study (Hair Jr et al., 2014).

The research model is an abstraction of the facts or phenomena that exist and being examined. In this study, we would explore the determinants of undergraduate students' financial literacy. The used specification of the econometric model is a multiple linear regression model. The model can be specified as follows:

$$
Y_{i}=f(X i, Z i)
$$

The $Y i$ is the student- $i$ financial literacy; $X i$ is the main independent variable consisting of financial education $(F E)$, socioeconomic status (SES), and gender $(G)$. The $Z i$ consists of control variables. They consist of prior school $(P S)$, faculty $(F)$, work status (WS), marital status $(M S)$, age $(A)$, birth order number $(B O N)$, number of siblings $(N S)$, number of family members $(F M)$, involvement in student organizations (ISO), ethnicity (ET), parents' demographic status $(P D S)$, region $(R)$, and distance $(D)$.

\section{RESULT AND DISCUSSION}

The This section outlines the characteristics of the sample based on certain criteria. It was aimed that the selected sample could be clearly described based on the criteria of gender, age, religion, the distance between students' house and campus, and the faculty from the sample of 325 . Table 1 showed the number of male samples by $28.83 \%$, while female students were 231 by $71.17 \%$. In other words, the research sample of the female students was three times greater than male students.

Table 1 also illustrated that the youngest student was 17 years old, the oldest was 48 years old, and the average student's age was 21.20. The number of older than the average respondents was 105 or $32.51 \%$, while the younger than the average was 220 or $67.49 \%$. Furthermore, most respondents were Muslim. It was $99.39 \%$ or 323 students, while the respondents of Non-Islamic were $0.61 \%$ or as many as 2 students. Meanwhile, respondents who lived more than $8 \mathrm{~km}$ reached $48.77 \%$ or as many as 158 students in terms of distance. The respondents who lived closest to the 
campus or less than $1.5 \mathrm{~km}$ were 12 students or $3.68 \%$. Meanwhile, other respondents whose distance of $1.5-7.99$ $\mathrm{km}$ from the campus, represented by 154 students or $47.24 \%$ of all respondents.

This study generally lived in urban areas $61.35 \%$ or as many as 200 students, while respondents who lived in rural areas were $38.65 \%$. The Economics and Business Faculty and the Teacher Training and Education Faculty were the most of the respondents. It was $32.21 \%, 28.53 \%$, respectively. In contrast, the least respondents were the Faculty of Engineering and the Faculty of Law. It was $4.2 \%$ and $9.20 \%$, respectively.

The main variables described in this study were financial literacy $(F L)$ as the dependent variable, while financial education $(F E)$, parents' socioeconomic status (SES), and gender $(G)$ were the independent variables. The results of data processing, as shown in Table 2 explained the average value and standard deviation of the financial literacy variable $[M=177.04$; $S D=17.46]$. It interpreted that the average of students' financial literacy score of the Syekh-Yusuf Islamic University was $80.47 \%$ that considered a high category. Thus, all of the sample students acquired good financial literacy skills and understanding.

Table 2 also explained the average value and standard deviation of the financial education variable was $[M=0.557$; $S D=0.497]$. It meant that $55.7 \%$ of the total samples had attended financial education through non-formal or formal education. Parents' socioeconomic status variable acquired $[M=75.38 ; S D=10.193]$ and the gender $[M=0.7138 ; S D=0.4526]$. These results showed the socioeconomic status of the parents of the Syekh-Yusuf Islamic University students was in the moderate category, or it was $75.38 \%$. Meanwhile, the number of female students as a sample was $71.38 \%$ of the total selected sample.

The first required analysis test was the data normality test. The test on the research variables employed Shapiro-Wilk and Shapiro-Franca. In the Shapiro-Wilk test criteria, if the probability value $>0.05$, then the data is declared as normally distributed. While the criteria for the Shapiro-Francia test claimed if the value $($ Prob $>\mathrm{z})>0.05$, then the data is considered normally distributed. The results of normality testing with the Shapiro-Francia test, as shown in Table 2, showed that the probability value $>\mathrm{z}$ for each variable of financial literacy and parents' socioeconomic status was 0.084 > 0.05 and $0.175>0.05$. It concluded that the data of two variables were normally distribution

The result of the multicollinearity test showed that the value of the variance inflation factor (VIF) test was between $1.08-5.07$ or the average of $1.93<10$. The VIF value was smaller than 10 , so it concluded that the regression model was free from multicollinearity problems. Meanwhile, the results of the heteroscedasticity test showed that the Breush-Pagan/Cook-Weisberg test obtained a value of $\mathrm{Chi}^{2}=1.29$ and (Prob > $\mathrm{Chi}^{2}$ ) of $0.2566>0.05$. It interpreted that the linear regression model has been free from the problem of heteroscedasticity.

Meanwhile, the goodness of fit results illustrated the $F$-stat value, significance, and $R^{2}$ value. The test results indicated the $F$-test value $=6.39$, the $p$ value $=0.000$, and the Adjusted $R^{2}$ value $=$ 0.2103 . The results that at least there was an influence of socioeconomic status variables, high school origin, birth serial number, number of siblings, parents' demographic status, and urban areas that significantly increased students' financial literacy. The value of Adjusted $R^{2}$ meant that $21.03 \%$ of financial literacy could be explained by the used variables in the model, while other variables outside the model explained the remaining $78.97 \%$.

In addition, we investigated the effect of financial education, socioeconomic status, gender, and control variables on students' financial literacy. Table 3 showed that the coefficient value 
of financial education $(F E)$ variable was 0.116 and the significance value of $p$-value $=0.976>0.05$. These results inferred that financial education had no significant effect on students' financial literacy $\left(\mathrm{H}_{1}\right.$ was not proven). The coefficient value of the parent's socioeconomic status variable $(S E S)$ was 0.682 and the significance value of $p$-value $=0.000<0.01$. These results indicated that the parent's socioeconomic status significantly affected students' financial literacy $\left(\mathrm{H}_{2}\right.$ was proven). This value suggested that for every 1 unit increase in parents' socioeconomic status, the financial literacy escalated by 0.682 units. It meant that the higher the parent's socioeconomic status, the more financial literacy would increase, assuming other factors were static.

The Gender variable $(G)$ obtained a coefficient value of 1.288 and a significance value of $p$-value $=0.532>$ 0.05 . These results showed that gender has no significant effect on student's financial literacy $\left(\mathrm{H}_{3}\right.$ was not proven). The control variables that significantly affected the increase of student's financial literacy were marital status variable $(M S)$, birth order number $(B O N)$, number of siblings $(N S)$, parents' demographic status $(P D S)$, and region $(R)$. Control variables that insignificantly affect students' financial literacy were prior school $(P S)$, faculty $(F)$, learning time $(L T)$, ethnicity $(E T)$, involvement in student organizations (ISO), and the distance between the house and campus $(D)$.

Testing the first hypothesis (H1) indicated that financial education was not significantly improving students' financial literacy. It meant that students' experience in attending financial education through formal education, short courses, seminars, workshops, etc., were not considered essential factors in improving students' financial literacy. The results of the study illustrated that there were $55.69 \%$ of the entire students of Syekh-Yusuf Islamic University had attended financial education. The knowledge, understanding, and ability about financial literacy could be obtained through daily life experiences in the work office, the community, the family, or independently read in various works of literature.

Even though effective and efficient education would change students in terms of their ability to understand better, assess, and take actions related to finances (Melmusi (2017). In fact, for countries with generally low incomes or less educated people, there had been many changes to the curriculum by including financial content in education, especially for (Kozup \& Hogarth, 2008). A more notorious research finding was conducted by (Frisancho, 2020) that claimed compulsory financial education for students has a more significant effect on financial literacy than elective after school programs of financial education.

Higher education, an educational service institution for citizens aged over 18 years, participates in improving the students' financial literacy. In line with U.S. Financial Literacy and Education Commission (2019), higher education prepared its students to make financial choices throughout their lives that enable the students to participate effectively in economic activities, improve wealth, and achieve their goals. Important decisions that were made by students and their families before, during, and after completing undergraduate studies affected their future finances.

The results of this study were not suitable with other research that concluded the financial education was positively and significantly related to the student's achievement of financial literacy (Brugiavini et al., 2020; Cordero et al., 2019; Özdemir, 2019). At the same time, the implementation of good financial education has a positive effect and shaping student's behavior in the long term (Wagner \& Walstad, 2019). In other words, students' good knowledge and understanding change the behavior in current and future life in making financial 
decisions because students have good financial literacy. Therefore, financial education included in various subjects with a cross-curricular approach was very important to improve students' financial literacy (Cordero et al., 2019).

Socioeconomic status represented the community's recognition and financial ability to have adequate resources in the family to meet their needs. There also found convincing results about the influence of socioeconomic factors on financial literacy. The results of hypothesis testing indicated that the parent's socioeconomic status had a significant effect on students' financial literacy $\left(\mathrm{H}_{2}\right.$ was accepted). It implied the higher of parents' socioeconomic status, the better the student acquires their financial literacy. Also, the high socioeconomic status of parents ultimately influences students to take economic actions and be careful in managing finances because they have been trained since childhood (Qomariyah et al., 2019).

The results of this study were in line with research conducted by (Garg \& Singh, 2018) which found that socioeconomic status contributed significantly to financial knowledge, financial attitudes, and financial behavior. Likewise, previous research by (Oseifuah et al., 2018) found that the higher parents' income, the greater the probability of the students' financial literacy improvement. Another previous study found that family background as measured by father's income and education was a significant correlation with financial literacy; on the other hand, mother's education was not (Mimura et al., 2015; Suherman et al., 2020).

However, this research findings were inconsistent with research conducted by (Bumcrot et al., 2013) which found that family economic conditions negatively correlated with financial literacy. Meanwhile, children from low-income families tend to have higher financial literacy (positive and significant correlation). Furthermore, another result found that parents' income did not significantly correlate with students' financial literacy (Khusaini et al., 2021). Students with high socioeconomic status parents tend to behave extravagantly and are less skilled in determining their consumption priorities. Students easily found finances' access from their parents. Thus, good financial planning was considered unnecessary.

The test results showed that gender had no significant effect on students' financial literacy $\left(\mathrm{H}_{3}\right.$ was rejected). It illustrated that students' gender was not a determinant for changing financial literacy. In other words, female and male students had a similar level of financial literacy. Students' aspects of knowledge, behavior, and attitudes in terms of finances did not depend on gender but are more influenced by the economic conditions of their families. Therefore, this finding was inconsistent with (Margaretha \& Pambudhi, 2015; Wijayanti et al., 2016) found that a female determined financial literacy. A contradictory result was found by (Oseifuah et al., 2018; Xue et al., 2019) that gender significantly affected financial literacy.

On the other hand, the results of this study confirmed the previous findings that gender did not affect students' financial literacy (Blasch et al., 2018; Egesta et al., 2021; Irman, 2018; Irman \& Fadrul, 2018; Salas-Velasco et al., 2020; Silta \& Miharti, 2020; Suherman et al., 2020). The current research was with previous findings because of the gender measurement, which merely employed a dummy variable for the female gender. This measurement did not reflect the nature and behavior of individuals. In addition, researchers could not explore female students who tend to be more emotional and unable to train selfcontrol. On the contrary, the man generally has logical and simple thinking in deciding something and more courageous and confident.

The current study has several limitations during the research process. 
Research limitations can arise from the preparation, implementation, methods, data analysis, and conclusions. The limitation of this research is only one university as the research population, so that the authors difficult to generalize. Respondents' perceptions expressed through questionnaires did not necessarily reflect the overall students' condition in the Tangerang Municipality regarding the level of financial literacy. For this reason, future research requires a broader target population, such as students of the Tangerang municipality or the Banten province. Another limitation is the measurement of financial literacy using a Likert scale, and it was least to reflect the ability, knowledge, and understanding of students' financial literacy. Therefore, in future research, it is necessary to measure student financial literacy in the form of multiple-choice questions to determine the actual literacy knowledge of the students.

Table 1. Profile Respondents

\begin{tabular}{|c|c|c|c|}
\hline Aspect & Criteria & Numbers & Percentage \\
\hline \multirow[t]{2}{*}{ Gender } & Male & 94 & 28.62 \\
\hline & Female & 231 & 71.38 \\
\hline \multirow[t]{5}{*}{ Age } & Highest & 48 & \\
\hline & Lowest & 17 & \\
\hline & Average & 21.20 & \\
\hline & $\geq$ Average & 105 & 32.51 \\
\hline & $<$ Average & 220 & 67.49 \\
\hline \multirow[t]{2}{*}{ Religion } & Islamic & 323 & 99.39 \\
\hline & Non-Islamic & 2 & 0.61 \\
\hline \multirow[t]{6}{*}{ Distance } & $<1.5 \mathrm{~km}$ & 12 & 3.68 \\
\hline & $1.5 \mathrm{~km}-3.49 \mathrm{~km}$ & 45 & 13.80 \\
\hline & $3.5 \mathrm{~km}-4.99 \mathrm{~km}$ & 45 & 13.50 \\
\hline & $5 \mathrm{~km}-6.49$ & 29 & 8.90 \\
\hline & $6.5 \mathrm{~km}-7.99 \mathrm{~km}$ & 36 & 11.04 \\
\hline & $\geq 8 \mathrm{~km}$ & 158 & 48.77 \\
\hline \multirow[t]{2}{*}{ Urban-Rural } & Urban & 200 & 61.35 \\
\hline & Rural & 125 & 38.65 \\
\hline \multirow[t]{6}{*}{ Faculty } & Teacher and Training Faculty & 93 & 28.53 \\
\hline & Technique Faculty & 14 & 4.29 \\
\hline & Social and Political Science Faculty & 43 & 13.19 \\
\hline & Law Faculty & 29 & 9.01 \\
\hline & Economic and Business Faculty & 105 & 32.19 \\
\hline & Islamic Religion Faculty & 41 & 12.58 \\
\hline
\end{tabular}


Table 2. Statistical Description

\begin{tabular}{cccccc}
\hline Variables & Obs & Mean & Std. Dev. & Min & Max \\
\hline$F L$ & 325 & 177.0369 & 17.45979 & 118 & 220 \\
$F E$ & 325 & 0.556923 & 0.497515 & 0 & 1 \\
$S E S$ & 325 & 75.37846 & 10.19357 & 41 & 100 \\
$G$ & 325 & 0.713846 & 0.452659 & 0 & 1 \\
$P S$ & 325 & 0.627692 & 0.484165 & 0 & 1 \\
$F$ & 325 & 0.495385 & 0.50075 & 0 & 1 \\
$W S$ & 325 & 0.655385 & 0.475976 & 0 & 1 \\
$M S$ & 325 & 0.947692 & 0.22299 & 0 & 1 \\
$A$ & 325 & 21.20308 & 3.10545 & 17 & 48 \\
$B O N$ & 325 & 1.993846 & 1.337941 & 1 & 10 \\
$N S$ & 325 & 2.224615 & 1.370549 & 0 & 9 \\
$F M$ & 325 & 4.723077 & 1.417567 & 1 & 15 \\
$I S O$ & 325 & 0.418462 & 0.494067 & 0 & 1 \\
$E T$ & 325 & 0.341539 & 0.474957 & 0 & 1 \\
$P D S$ & 325 & 0.504615 & 0.50075 & 0 & 1 \\
$R$ & 325 & 0.615385 & 0.487255 & 0 & 1 \\
$D$ & 325 & 0.510769 & 0.500655 & 0 & 1 \\
\hline
\end{tabular}

Table 3. The Regression Results

\begin{tabular}{lccc}
\hline \multicolumn{1}{c}{ Variables } & Coefficient & S.E & Sig \\
\hline$F E$ & 0.116 & 3.851 & 0.976 \\
$S E S$ & 0.682 & 0.088 & 0.000 \\
$G$ & 1.288 & 2.061 & 0.532 \\
$P S$ & -0.562 & 1.861 & 0.763 \\
$F$ & 2.405 & 3.876 & 0.535 \\
$W S$ & 2.086 & 2.066 & 0.313 \\
$M S$ & -11.177 & 4.574 & 0.015 \\
$A$ & -0.258 & 0.368 & 0.484 \\
$B O N$ & 1.836 & 0.900 & 0.042 \\
$N S$ & -2.255 & 1.063 & 0.035 \\
$F M$ & 0.013 & 0.853 & 0.988 \\
$I S O$ & 3.736 & 2.012 & 0.064 \\
$E T$ & -2.544 & 2.070 & 0.220 \\
$P D S$ & 1.223 & 1.875 & 0.515 \\
$R$ & 4.873 & 1.956 & 0.013 \\
$D$ & 0.593 & 1.869 & 0.751 \\
\hline Constanta & 134.992 & 13.215 & 0.000 \\
\hline Obs & 325 & & \\
R-squared & 0.2493 & & \\
Adj. R-squared & 0.2103 & & \\
F(16, 308) & 6.39 & & \\
Prob $>$ F & 0.000 & & \\
\hline
\end{tabular}




\section{CONCLUSION AND RECOMMEN- DATION}

The After discussing the results, the authors conclude that student financial literacy is in the moderate category. The relationship between variables found that the parents' socioeconomic status is a significant determinant in increasing student financial literacy, while financial education and gender are not. It means that the higher of family socioeconomic conditions, the stronger the student's financial literacy will increase. In other words, students who come from wealthy families tend to have better levels of financial literacy skills because students gain experience in making financial decisions in their daily family life.

The test results showed that financial education has no significant effect on financial literacy. This result implied that financial education is required, neither formal nor non-formal education. Individual financial decisions are gained more from life experiences. Students can make their financial plans, spend money on consumption, and evaluate their decisions. Early in the life cycle, the provided financial education may benefit from debt or long-term savings and may even extend beyond the financial domain. Thus, financial education enhances the understanding of financial affairs but appears to have broader implications on welfare, similar to other forms of education (Kaiser \& Menkhoff, 2020).

The socioeconomic status is illustrated to significantly increase students' financial literacy, implying that the more prosperous parents can provide financial management experience to their sons and daughters. The interaction between parents and good communication created in the family has a positive effect on the attitudes and behavior of their children. Every time parents make a financial decision in the family. The children recognize it to learn financial literacy better. Therefore, the role of parents is very important as a policy instrument to increase student financial literacy.

The testing results of the gender variable found that gender did not significantly increase students' financial literacy. This result implies that gender is not an important variable in determining policies in improving financial literacy and, more broadly, improving welfare in the future. For universities, building communication with parents is very important. Given that parents have an important role in determining the welfare of their children. In addition, the form of communication can be through seminars, annual awards for the parents whose children excel and involving parent representatives in formulating university programs directly.

Meanwhile, students should continuously improve their abilities, understanding, and skills directly related to financial literacy. By having the ability, understanding, and financial literacy skills, students will prepare for a better future. Students can manage money according to their needs. Likewise, parents should always be the model for their children in terms of financial management. Parents need to continue in providing direction and guidance regarding financial decisionmaking.

For further research, we suggested employing a broader research population such as the district or city level. It is intended to facilitate the determination of the generalization area. In addition, future researchers should innovate in measuring students' financial literacy so that it reflects actual literacy, for example, by using a questionnaire about financial literacy with more indicators than the current research.

\section{ACKNOWLEDGMENT}

The authors would like to express their gratitude to the Institute of Research and Community Service (LPPM), which provides the research grant. The appreciation is also to co-authors for their assistance in investigating this research and 
writing this work. There is no conflict of interest in this paper publication. The authors also express their gratitude to anonymous reviewers of this article.

\section{REFERENCES}

Almenberg, J., \& Säve-Söderbergh, J. (2011). Financial Literacy and Retirement Planning in Sweden. Journal of Pension Economics and Finance, $\quad$ 10(04), 585-598. https://doi.org/10.2139/ssrn.1809736

Ansong, A., \& Gyensare, M. A. (2012a). Determinants of University WorkingStudents' Financial Literacy at the University of Cape Coast, Ghana. International Journal of Business and Management, 7(9), 126-133. https://doi.org/10.5539/ijbm.v7n9p12 6

Ansong, A., \& Gyensare, M. A. (2012b). Determinants of University WorkingStudents' Financial Literacy at the University of Cape Coast, Ghana. International Journal of Business and Management, 7(9). https://doi.org/10.5539/ijbm.v7n9p12 6

Askar, M. W., Quattara, B., \& Zhang, Y.F. (2020). Financial Literacy and Poverty Reduction: the Case of Indonesia (No. 1097; ADBI Working Paper Series). https://www.adb.org/publications/fina ncial-literacy-poverty-reduction-caseindonesia

Atkinson, A., \& Messy, F.-A. (2012). Measuring Financial Literacy: Results of the OECD/ International Network on Financial Education (INFE) Pilot Study. Oecd, 15, 1-73. https://doi.org/https://doi.org/10.1787/ bb2cd70c-en

Basrowi, \& Siti, J. (2010). Analisis kondisi sosial ekonomi dan tingkat pendidikan masyarakat Desa Srigading, Kecamatan Labuhan Maringgai, Kabupaten Lampung Timur. Jurnal Ekonomi \&
Pendidikan, 7(1), 58-81.

Becchetti, L., Caiazza, S., \& Coviello, D. (2013). Financial education and investment attitudes in high schools: Evidence from a randomized experiment. Applied Financial Economics, 23(10), 817-836. https://doi.org/10.1080/09603107.201 3.767977

Blasch, J., Boogen, N., Daminato, C., \& Filippini, M. (2018). Empower the Consumer! Energy-related Financial Literacy and its Socioeconomic Determinants (18/289; Economics Working Paper Series). https://cer.ethz.ch/content/dam/ethz/s pecial-interest/mtec/cer-eth/cer-ethdam/documents/working-papers/WP18-289.pdf

Brugiavini, A., Cavapozzi, D., Padula, M., \& Pettinicchi, Y. (2020). On the effect of financial education on financial literacy: Evidence from a sample of college students. Journal of Pension Economics and Finance, 19(3), 344352.

https://doi.org/10.1017/S1474747218 000276

Bumcrot, C., Lin, J., \& Lusardi, A. (2013). The Geography of Financial Misconduct. Numeracy, 6(2), 1-16. https://doi.org/http://dx.doi.org/10.50 38/1936-4660.6.2.2 Authors

Carpena, F., \& Zia, B. (2020). The causal mechanism of financial education: Evidence from mediation analysis. Journal of Economic Behavior and Organization, 177, 143-184. https://doi.org/10.1016/j.jebo.2020.05 .001

Chen, H. \&, \& P. Volpe, R. (1998). An Analysis of Personal Financial Literacy Among College Students. Financial Services Review, 7(2), 107128. https://doi.org/1057-0810

Chen, H., \& Volpe, R. (2002). Gender Differences in Personal Financial Literacy Among College Students. In Financial Services Review (Vol. 11, Issue 3, p. 289). 
Cole, S., Sampson, T., \& Zia, B. (2009). Financial Literacy, Financial Decisions, and the Demand for Financial Services: Evidence from India and Indonesia. https://www.researchgate.net/publicat ion/228420285_Financial_Literacy_F inancial_Decisions_and_the_Demand _for_Financial_Services_Evidence_fr om_India_and_Indonesia

Compen, B., De Witte, K., \& Schelfhout, W. (2019). The role of teacher professional development in financial literacy education: A systematic literature review. Educational Research Review, 26, 16-31. https://doi.org/10.1016/j.edurev.2018. 12.001

Cordero, J. M., Gil-Izquierdo, M., \& Pedraja-Chaparro, F. (2019). Financial education and student financial literacy: A cross-country analysis using PISA 2012 data. Social Science Journal. https://doi.org/10.1016/j.soscij.2019.0 7.011

Egesta, E., Rahayu, C. W. E., \& Rahmawati, C. H. T. (2021). Factors Affecting Student's Financial Literacy (A Study on the Students of the Faculty of Economics and The Faculty of Science and Technology of Sanata Dharma University Yogyakarta). Media Ekonomi Dan Manajemen, 36(1), 27-38. https://doi.org/http://dx.doi.org/10.24 856/mem.v36i1.1577

Frisancho, V. (2020). The impact of financial education for youth. Economics of Education Review, 78(October 2018), 101918. https://doi.org/10.1016/j.econedurev.2 019.101918

Garcia, R., \& Tessada, J. (2013). The Effect of Education on Financial Market Participation: Evidence from Chile (Working Paper Series Finance UC).

Garg, N., \& Singh, S. (2018). Financial literacy among youth. International
Journal of Social Economics, 45(1), 173-186.

https://doi.org/10.1108/IJSE-11-20160303

Gerardi, K., Götte, L., Meier, S., Goette, L., \& Meier, S. (2010). Evidence from a Survey Matched to Administrative Data (No. 10; Working Paper Series). http://www.frbatlanta.org/pubs/wp/wo rking_paper_2010-10.cfm

Gerrans, P., \& Heaney, R. (2019). The impact of undergraduate personal finance education on individual financial literacy, attitudes, and intentions. Accounting and Finance, 59(1),

177-217. https://doi.org/10.1111/acfi.12247

Ghozali, I. (2016). Aplikasi Analisis Multivariat dengan Prgram IBM SPSS 23 (P. P. Harto (ed.); Ketujuh). Universitas Diponegoro.

Grohmann, A., \& Menkhoff, L. A. (2015). School, parents, and financial literacy shape future financial behavior. $D I W$ Economic Bulletin, 5(30/31), 407412.

http://hdl.handle.net/10419/113233\% $0 \mathrm{~A}$

Hair Jr, J. F., Black, W. C., Babin, B. J., \& Anderson, R. E. (2014). Multivariate Data Analysis (Seventh). Pearson Education Ltd.

Hanson, T. A., \& Olson, P. M. (2018). Financial literacy and family communication patterns. Journal of Behavioral and Experimental Finance, 19, 64-71. https://doi.org/10.1016/j.jbef.2018.05. 001

Herd, P., Holden, K., \& Su, Y. T. (2012). The Links between Early-Life Cognition and Schooling and LateLife Financial Knowledge. Journal of Consumer Affairs, 46(3), 411-435. https://doi.org/https://doi.org/10.1111/ j.1745-6606.2012.01235.x

Homan, H. S. (2015). Comparative Study of Students Financial Literacy And Its Demographic Factors. First International Conference on 
Economics and Banking, 106-111. https://doi.org/10.2991/iceb-

15.2015.16

Indrawati, E. S., Soedharto, J., \& Semarang, S. T. (2015). Status Sosial Ekonomi Dan Intensitas Komunikasi Keluarga Pada Ibu Rumah Tangga Di Panggung Kidul Semarang Utara. Jurnal Psikologi Undip, 14(1), 52-57.

Irman, M. (2018). Analisis Faktor-Faktor Yang Mempengaruhi Financial Literacy di Kalangan Mahasiswa Universitas Muhammadiyah Riau (UMRI) Pekan Baru. Journal of Economic, Business and Accounting (COSTING), 1(2), 180-197. https://doi.org/https://doi.org/10.3153 9/costing.v1i2.205

Irman, M., \& Fadrul. (2018). Analisis Pengaruh Jenis Kelamin, IPK, dan Pengalaman Kerja terhadap Financial Literacy. Journal of Economic, Business and Accounting (COSTING), 2(1), 41-56. https://doi.org/https://doi.org/10.3153 9/costing.v2i1.345

Jariwala, H. V. (2015). Analysis of Financial Literacy Level of Retail Individual Investors of Gujarat State and Its Effect on Investment Decision. Journal of Business and Finance Librarianship, 20(September 2014), 133-158.

https://doi.org/10.1080/08963568.201 5.977727

Jayaraman, J. D., \& Jambunathan, S. (2018). Financial literacy among high school students: Evidence from India. Citizenship, Social and Economics Education, 17(3), 168-187. https://doi.org/10.1177/20471734188 09712

Kadoya, Y., \& Khan, M. S. R. (2020). What determines financial literacy in Japan. Journal of Pension Economics and Finance, 19(3), 353-371. https://doi.org/10.1017/S1474747218 000379

Kaiser, T., \& Menkhoff, L. (2020). Financial education in schools: A meta-analysis of experimental studies. Economics of Education Review, 78(September), 101930. https://doi.org/10.1016/j.econedurev.2 019.101930

Khusaini, Mutiah, \& Ramdani, C. R. (2021). Vocational and senior high school differences in financial literacy. 3rd International Conference on Environmental Geography and Geography Education, 1-14. https://doi.org/10.1088/17551315/747/1/012018

Klaper, L., Lusardi, A., \& Mitchell, O. S. (2015). Financial Literacy Around the World: Insight From the $S \& P$ Global Finlit Survey (Vol. 10, Issue 4). https://gflec.org/wpcontent/uploads/2015/11/Finlit_paper _16_F2_singles.pdf

Kothari, C. R. (2004). Research Methodology: Methods and Techniques (Second). New Age International (P) Ltd. www.newagepublishers.com

Kozup, J., \& Hogarth, J. M. (2008). Financial Literacy, Public Policy, and Consumers' Self-Protection-More Questions, Fewer Answers. Journal of Consumer Affairs, 42(2), 127-136. https://doi.org/https://doi.org/10.1111/ j.1745-6606.2008.00101.x

Lantara, I. W. N., \& Ni Ketut Rai Kartini. (2015). Financial Literacy Among University Students : Empirical Evidence From Indonesia. Journal of Indonesian Economy and Business, 30(3),

247-256. https://doi.org/https://doi.org/10.2214 6/jieb.10314

Liu, J., Peng, P., \& Luo, L. (2020). The Relation Between Family Socioeconomic Status and Academic Achievement in China: A Metaanalysis. Educational Psychology Review, 32, 49-76. https://doi.org/https://doi.org/10.1007/ s10648-019-09494-0

Lührmann, M., Serra-Garcia, M., \& Winter, J. (2015). Teaching teenagers 
in finance: Does it work? Journal of Banking and Finance, 54(November), 160-174.

https://doi.org/10.1016/j.jbankfin.201 4.11.009

Lusardi, A. (2003). Saving and the Effectiveness of Financial Education. In O. S. Mitchell \& S. P. Utkus (Eds.), Pension Design and Structure: New Lessons from Behavioral Finance (Eds, pp. 157-184). Oxford University Press. https://repository.upenn.edu/prc_pape rs/430

Lusardi, A. (2019). Financial literacy and the need for financial education: evidence and implications. Swiss Journal of Economics and Statistics, 155(1), 1-8. https://doi.org/10.1186/s41937-0190027-5

Lusardi, A., \& Mitchell, O. S. (2011a). Financial Literacy And Retirement Planning In The United States. In National Bureau Of Economic Research (No. 17108; NBER Working Paper). https://www.nber.org/papers/w17108

Lusardi, A., \& Mitchell, O. S. (2011b). Financial Literacy Around the World: An Overview. Journal of Pension Economics and Finance, 10(4), 497508.

https://doi.org/10.1017/S1474747211 000448

Lusardi, A., \& Mitchell, O. S. (2013). The Economic Importance of Financial Literacy: Theory and Evidence. In NBER Working Paper Series (No. 18952; Working Paper). http://www.nber.org/papers/w18952

Lusardi, A., \& Mitchell, O. S. (2014). The Economic Importance of Financial Literacy: Theory and Evidence. Journal of Economic Literature, 52(1), 5-44. https://doi.org/10.1257/jel.52.1.5

Lusardi, A., Mitchell, O. S., \& Curto, V. (2009). Financial Literacy Among the Young: Evidence and Implications for
Consumer Policy. In PRC Working Paper (No. 2009-09; PRC WP). http://ssrn.com/abstract $=1459141$

Mandell, L. (2008). Financial Literacy of High School Students. In J. J. Xiao (Ed.), Handbook of Consumer Finance Research (Eds, pp. 163-183). Springer. https://doi.org/10.1007/9780-387-75734-6_10

Margaretha, F., \& Pambudhi, R. A. (2015). Tingkat Literasi Keuangan Pada Mahasiswa S-1. Jurnal Manajemen Dan Kewirausahaan, 17(1), 76-85. https://doi.org/10.9744/jmk.17.1.76

Melmusi, Z. (2017). Faktor Faktor Yang Mempengaruhi Literasi Finansial Mahasiswa Fakultas Ekonomi (Studi Kasus di Universitas Putra Indonesia "YPTK" Padang). Majalah Ilmiah, 24(2), 221-229.

Mimura, Y., Koonce, J., Plunkett, S. W., \& Pleskus, L. V. O.-26. (2015). Financial Information Source, Knowledge, and Practices of College Students from Diverse Backgrounds. Journal of Financial Counseling and Planning, 26(1), 63-78. https://doi.org/10.1891/10523073.26.1.63

Mishra, M. K. (2019). Financial Literacy and Education for Improving Financial Skills. SSRN Electronic Journal, $1-21$. https://doi.org/10.2139/ssrn.3488670

Munisah, \& Khusaini. (2017). Pengaruh Gender, Status Bekerja, dan Status Perkawinan terhadap Prestasi Akademik. Jurnal Ilmiah KREATIF, 5(1), 76-98.

Mustapha., M., \& Jeyaram, S. (2015). Financial literacy and demographic factors. In Journal of Technology Management and Business (Vol. 2, Issue 1).

Nababan, D., \& Sadalia, I. (2012). Analisis personal financial liteacy dan financial behavior mahasiswa strata I fakultas ekonomi Universitas Sumatera Utara. Media Informasi Manajemen, 1, 1-16. 
Nanda, A. K., \& Samanta, S. (2018). Mainstreaming tribals through financial literacy - a review of literature. International Journal of Social Economics, 45(2), 437-444. https://doi.org/10.1108/IJSE-12-20160371

Organisation for Co-operation and Development. (2013). PISA 2012: Financial Literacy Framework. http://www.oecd.org/finance/financial

education/PISA2012FrameworkLitera cy.pdf

Organisation for Economic Co-operation and Development. (2020). PISA 2018 Results (Volume IV): Are Students Smart About Money? Vol. IV (M. Achiron (ed.)). OECD Publishing. https://doi.org/10.1787/48ebd1ba-en

Oseifuah, E., Gyekye, A., \& Formadi, P. (2018). Financial literacy among undergraduate students: Empirical evidence from Ghana. Academy of Accounting and Financial Studies Journal, 22(6), 1-17.

Otoritas Jasa Keuangan. (2019). Siaran Pers Survei OJK 2019: Indeks Literasi Dan Inklusi Keuangan Meningkat (p. 1). Otoritas Jasa Keuangan.

https://www.ojk.go.id/id/berita-dankegiatan/siaran-pers/Pages/SiaranPers-Survei-OJK-2019-IndeksLiterasi-Dan-Inklusi-KeuanganMeningkat.aspx

Özdemir, O. (2019). Rethinking the financial Kuznets curve in the framework of income inequality: Empirical evidence on advanced and developing economies. Economics and Business Letters, 8(4), 176-190. https://doi.org/10.17811/ebl.8.4.2019. 176-190

Qomariyah, S. N., Harti, \& Hariyati. (2019). Social Interaction, SocioEconomic Status, and Basic Economic Knowledge of Students' Economic Behavior. Jurnal Pendidikan Ekonomi Dan Bisnis
(JPEB), $\quad 7(2), \quad 101-111$. https://doi.org/10.21009/jpeb.007.2.1

Radityas, M. D., \& Pustikaningsih, A. (2019). Analysis of the Factors That Influence Students' Level of Financial Literacy. Jurnal Pendidikan Akuntansi Indonesia, 17(1), 42-56. https://doi.org/10.21831/jpai.v17i1.26 336

Rafinda, A., \& Gal, T. (2020). Financial Literacy of Economics and NonEconomics Students. International Review of Management and Marketing, 10(3), 35-38. https://doi.org/10.32479/irmm.8974

Riitsalu, L., Murakas, R., \& Veeret, D. (2018). Disentangling financial literacy: Threedimensional approach to analysing management of personal finances in Estonia. Journal of Social Research and Policy, 9(1), 29-40.

Rita, M. R., \& Pesudo, B. C. A. (2014). Apakah Mahasiswa Sudah Melek Keuangan? Dinamika Akuntansi, Keuangan Dan Perbankan, 3(1), 5865.

Salas-Velasco, M., Moreno-Herrero, D., \& Sánchez-Campillo, J. (2020). Teaching financial education in schools and students' financial literacy: A cross-country analysis with PISA data. International Journal of Finance and Economics, June 2018.

https://doi.org/10.1002/ijfe.2005

Sarpong-Danquah, B., Gyimah, P., Poku, K., \& Osei-Poku, B. (2018). Financial Literacy Assessment on Tertiary Students in Sub-Saharan Africa: A Ghanaian Perspective. International Journal of Accounting and Financial Reporting, $\quad 8(2), \quad 76$. https://doi.org/10.5296/ijafr.v8i2.1292 8

Senda, D. A., Rahayu, C. W. E., \& Tri Rahmawati, C. H. (2020). The Effect of Financial Literacy Level and Demographic Factors on Investment Decision. Media Ekonomi Dan Manajemen, $\quad 35(1), \quad 100$. 
https://doi.org/10.24856/mem.v35i1.1 246

Seotsanyana, M. E. (2019). Assessment of university students' level of financial literacy: the voices of the National University of Development Studies education students. Africa Review, 11(1), 63-76. https://doi.org/10.1080/09744053.201 8.1538680

Setiawan, B. (2020). Descriptive Analysis of Financial Literacy: Evidence from Public and Private University Students in Indonesia. Sriwijaya International Journal of Dynamic Economics and Business, 4(1), 73. https://doi.org/10.29259/sijdeb.v4i1.7 3-86

Setyorini, N., Indiworo, R. H. E., \& Sutrisno. (2021). The Role Financial Literacy and Financial Planning to Increase Financial Resilience: Household Behaviour as Mediating Variable. Media Ekonomi Dan Manajemen, 36(2), 243-255. https://doi.org/10.24856/mem.v36i2.2 179

Shaari, N. A., Hasan, N. A., Mohamed, R. K. M. H., \& Sabri, M. A. J. M. (2013). Financial Literacy: A Study Among The University Students. Interdisciplinary Journal of Contemporary Research in Business, 5(2), 279-299.

Silta, H. P., \& Miharti, I. (2020). Factors Affecting The Level Of Financial Literation In College Student. Jambura Science of Management, 2(1), 15-23. https://doi.org/10.37479/jsm.v2i1.443 5

Son, J., \& Park, J. (2019). Effects of financial education on sound personal finance in Korea: Conceptualization of mediation effects of financial literacy across income classes. International Journal of Consumer Studies, 43(1), 77-86. https://doi.org/10.1111/ijcs.12486

Soseco, T., Wulandari, D., Hadi Utomo, S.,
\& Narmaditya, B. S. (2018). House Ownership Circumstances in Rural Area: Evidence from Indonesia. Jurnal Pendidikan Ekonomi Dan Bisnis (JPEB), 6(2), 93-102. https://doi.org/10.21009/jpeb.006.2.2

Suherman, A., Wardani, Kartika Puspa, E., \& Khusaini. (2020). Analisis Literasi Keuangan Mahasiswa di FKIP UNIS Tangerang. Jurnal Pendidikan Ekonomi, 13(1), 18-29. https://doi.org/https://dx.doi.org/10.17 977/UM014v13i12020p018

Susanti, \& Hardini, H. T. (2018). Gender, academic achievement, and ownership of ATM as predictors of accounting students' financial literacy. IOP Conference Series: Materials Science and Engineering PAPER, 296, 1-7. https://doi.org/10.1088/1757899X/296/1/012031

Thompson, S. (2014). Financing the future: Australian students' results in the PISA 2012 Financial Literacy assessment. Australian Council for Educational Research. https://research.acer.edu.au/cgi/viewc ontent.cgi article $=1016 \&$ context $=\mathrm{ozp}$ isa

U.S. Financial Literacy and Education Commission. (2019). Best practices for financial literacy and education at institutions of higher education: https://arc.accesslex.org/fedelivery/18/

Van Campenhout, G. (2015). Revaluing the Role of Parents as Financial Socialization Agents in Youth Financial Literacy Programs. Journal of Consumer Affairs, 49(1), 186-222. https://doi.org/https://doi.org/10.1111/ joca. 12064

Wagner, J., \& Walstad, W. B. (2019). The Effects of Financial Education on Short-Term and Long-Term Financial Behaviors. Journal of Consumer Affairs, 53(1), 234-259. https://doi.org/10.1111/joca.12210

Wijayanti, Agustin, G., \& Rahmawati, F. 
(2016). Pengaruh jenis kelamin, IPK, dan semester terhadap literasi keuangan mahasiswa prodi S1 Ekonomi Pembangunan Universitas Negeri Malang. Jurnal Pendidikan Ekonomi, 09(1), 87-96. https://doi.org/: https://dx.doi.org/10.17977/UM014v0 9i12016p088

Xu, L., \& Zia, B. (2012). Financial Literacy around the World: An Overview of the Evidence with Practical Suggestions for the Way Forward (No. 6107; Policy Research Working Paper). http://hdl.handle.net/10986/9322

Xue, R., Gepp, A., O’Neill, T. J., Stern, S., \& Vanstone, B. J. (2019). Financial literacy amongst elderly Australians. Accounting and Finance, 59(S1), 887-918.

https://doi.org/10.1111/acfi.12362

Yuxiao, W., \& Chao, H. (2017). School Socioeconomic Segregation and Educational Expectations of Students in China's Junior High Schools. Social Sciences in China, 38(3), 112126.

https://doi.org/10.1080/02529203.201 7.1339449

Zhao, N., Valcke, M., Desoete, A., \& Verhaeghe, J. P. (2012). The quadratic relationship between socioeconomic status and learning performance in China by multilevel analysis: Implications for policies to foster education equity. International Journal of Educational Development, 32(3), 412-422. https://doi.org/10.1016/j.ijedudev.201 1.08 .004 